\title{
高攀土質士石類の $\mathbf{X}$ 線 的研究(第 $\mathbf{I}$ 報)
}

\author{
藍晶石の加熱變化に就て
}

秋山 桂 一

\section{（1）緒言}

高攀土質土石類认は種々暴るものが多々ある。 それ等の物理的並 に化學的性質を知り適切な處理法を講ずる事は高級な高攀土質耐火 物を製造する上に於ては缺くべからざる事である。從來本邦に於て は高攀土質の原料としては三石のダイアスポア，復州の硬質粘土等 が主として使用されて居たが，近來は北支那の長城粘土，冀東粘土， 其の他滿支に産する攀土頁岩の利用が旺になり，更に數年前よりサ イアナイト (Cyanite)，郎ち藍晶石より特殊の 高攀土質耐火物が製 造されつ」ある. 北支那の䙪土頁岩にはアルミナ $80 \%$ に達する樣 な高禁土質のものがあるが，同地方のものでアルミナ $50 \%$ 以上のも のは最近 3,4 年前より急激に使用される樣になつたものであり, 使用者側に於ても充分の研究が行はれて居ない點も女り, 更に又原 料其のものに鐵分の多いものがあつたり, 或は又ダイアスポアとカ オリンの混合物のため熱的性質が複雜であつたりして，これを完全 に使ひこなす迄には至つて居ない樣である. 然るに藍晶石の如きは アルミナ分は攀土頁岩の高攀土のものより少いにもか」はらずこれ より造つた煉瓦は攀土頁岩より造つたものより各種の性質に於て非 常に優れて居る. $\mathrm{Al}_{2} \mathrm{O}_{3} \cdot \mathrm{SiO}_{2}$ には藍晶石以外に紅桂石 (Andalusite), 珪線石 (Sillimanite) がある事が知られて居るが，年れ等は一層優秀 な性質があると考へられて居る，不幸にして之等のものは本邦には 從來殆どなく, 鏬物標本の程度に於て福島縣石川郡に紅杜石を, 香 川縣綾香郡より珠線石，紅杜石を出して居るに過ぎなかつた．近時 朝鮮に藍晶石及び紅杜石の相當な鑛床が發見され著者の研究窒にも 見本が潜られて來たが，大變立派なものであるがこれは今後の開發 に俟たねばならぬ. 南洋群島パラオ島一帶及び海南島附近にはボー キサイト(驖分多き模樣) が埋藏されて居り, 我國も溸次各種高䙪 土質の原料に惠ぐまれて來るかも知れ好. 然しながら何と言つても 多量にあるのは北支那及び满洲の攀土頁岩である. 故に其の利用に 就ては徹底的に呼究する必要があると思ふ。

著者は各種高攀土質土石類の諸性質を基碟的に比較研究する必要 ありと考へ，差し當りX線的研究を中心として押し進め，次で各種 原料の處理方法を考へ，更に應用の研究をなし高攀土質にして而も 高級な耐火物の製造に資したいと思ふ。

著者は先づ藍晶石の加熱變化の研究を進め, 次で紅杜石, 珪線石, 攀土頁岩, ボーキサイト等の研究を行つた。 夫等に關し逐次報告し たいと考へる.

\section{（2） 珪線石屬鑛物及ムライトの概念}

シリマナイト屬鑛物及びムライトの概念に就ては一般に知られて 居る事と考へるが，本研究の中心をなすものであるから爱に一應覺 書として書き記して置きたい。

$\mathrm{Al}_{2} \mathrm{O}_{3}$ 一 $\mathrm{SiO}_{2}$ 系には 2 種の化合物が存在する事が知られて居る, 郎ち $\mathrm{Al}_{2} \mathrm{O}_{3} \cdot \mathrm{SiO}_{2}$ 及 $3 \mathrm{Al}_{2} \mathrm{O}_{3} \cdot 2 \mathrm{SiO}_{2}$ である. $\mathrm{Al}_{2} \mathrm{O}_{3} \cdot \mathrm{SiO}_{2}$ には同質異 像體が 3 種天然に童出する, 郎ち珪線石，藍晶石，紅杜石である.
$3 \mathrm{Al}_{2} \mathrm{O}_{3} \cdot 2 \mathrm{SiO}_{2}$ にはムル石又はムライト (Mullite) が天然に莣出し又 人工的にも造られる。珪線不，藍晶石，紅桂不は鑛物學上珪線石屬 に大れられてある，之等の中珪線不は廈く天然に分布して居るが大 量には蒦出せず，藍晶石及び紅杜石は相當大きなポケット又はデポ ジットをなして印度，アメリカ等には多量に産出する樣である。本 邦に於ては緒言にも述べた樣に標本程度しか出なかつたが近來香川 縣の珠線不，紅桂不は工業的に利用されて居る樣である. 朝蘚のも のは目下開發されつ」ある.ムライトはムル島 (Isle of Mull) に少 量天然に發見された所からムライトの名糐が與へられたのである がこれは Bowen \& Greig 兩氏が 1924 年人工的合成實羷に於て $3 \mathrm{Al}_{2} \mathrm{O}_{3} \cdot 2 \mathrm{SiO}_{2}$ なる化合物を確認した直後のことなのでMullite なる 名棦が人工的のものにも天然のものにも與へられたものであらろ. 理線不，藍晶石，紅杜石は高溫に加熱するとムライトと珪酸硝子に なるので之等とムライトは同じすの〉樣に考へられ，特に珠線石と ムライトとは混同されて來た，之等の關係が最近に至り漸次明かに されて來た。

Bowen \& Greig 氏は $\mathrm{SiO}_{2}$ と $\mathrm{Al}_{2} \mathrm{O}_{3}$ を $1: 1$ に調合し人工的に 燒成して作つた化合物は天然のシリマナィトと異るものである事を 認め, これにムライトなる名籍を與へ其の分子式は $3 \mathrm{Al}_{2} \mathrm{O}_{3} \cdot 2 \mathrm{SiO}_{2}$ であると報じた事前述の如くである (J.Amer.Ceram.Soc., 1924, 7, 238), 而してムライトとシリマナイトは同じ Orthorhorhombic crystal で似て居るが其の屈折率に於て黑るとして次の樣な數字を 示した.

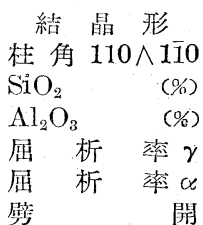

シリマナイト
Orthorhonibic
$88^{\circ} 15^{\prime}$
36.8
62.9
1.677
1.657
010

ムライト
Orthorhombic
$89^{\circ} 13^{\prime}$
27.5
73.0
1.654
1.642
010

J. T. Norton 氏 (J.Amer. Soc., 1925, 8, 401) は $\mathrm{Al}_{2} \mathrm{O}_{3}$ と $\mathrm{SiO}_{2}$ を 1:1 及 $3: 2$ の比に調合し $1500^{\circ} \mathrm{C}$ 以上に加熱したものに就て $\mathrm{X}$ 線解析を行つた所，兩者は全く天然の珪線石と同じ趣折線を與へ ると述べたが，前述の如く Bowen 氏等は 1 年前に昡微鏡的に此の 說を否定して居り, 更に叉 L. Navias \& N. P. Davey 雨氏 $(J$. Amer. Ceram. Soc., 1925, 8,640) は天然のシリマナイト及び合成么 ライト其の他を $\mathrm{X}$ 線解折した結果，各趣折線は何れも牛分はムライ トの線を含多他の牛分は他の物質を含んで居る事を認め, 結論とし てシリマナイトとムライトは極めてよく類似した線を持つて居るが $2.12 \AA$ と $1.70 \AA$ の範圍に於て斷然異ると述べた，郎ち第 1 表の如 くである.

第 1 表の諸砰究に依り天然のシリマナイトとムライトは顯微鏡的 にもX線的にも異るものであり，各成分よりシリマナイトを合成せ んとしても出來るものはシリマナイトではなくムライトである言ふ 事になり, 從つて其の際 $\mathrm{SiO}_{2}$ は一部遊離する事となり, それが如何 なる形になつて居るか或は又實際上煉瓦にした場合如何なる割合を 


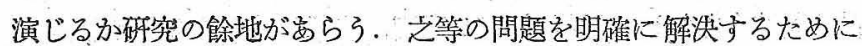
は先づ以て天然の珄線石屬鑛物の加熱分解に就て知る必要がある!

J. T. Norton 氏 (J.Amer. Ceram.Soc., 1925, 8,636) は紅柱石 は $1600^{\circ} \mathrm{C}$ 以上に於て熱變化が起り，藍晶石は $1450^{\circ} \mathrm{C}$ 以上に於て 起ると述べ，而して紅㤬石 $\left(17.00^{\circ} \mathrm{C}\right.$ 以上) 欢で監晶石 $\left(1500^{\circ} \mathrm{C}\right)$ 爟 成物の超折線は咯人工的合成物々類似すると述べた。

第 1 圆 藏晶石の顯微鏡寫蒖

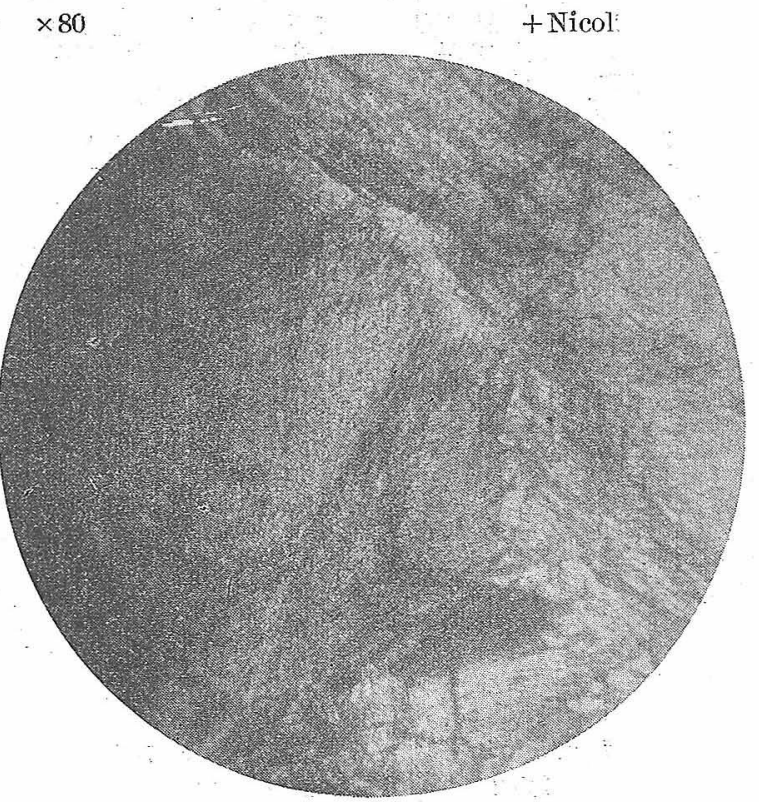

第 2 圖藍晶石の加蓺戀化
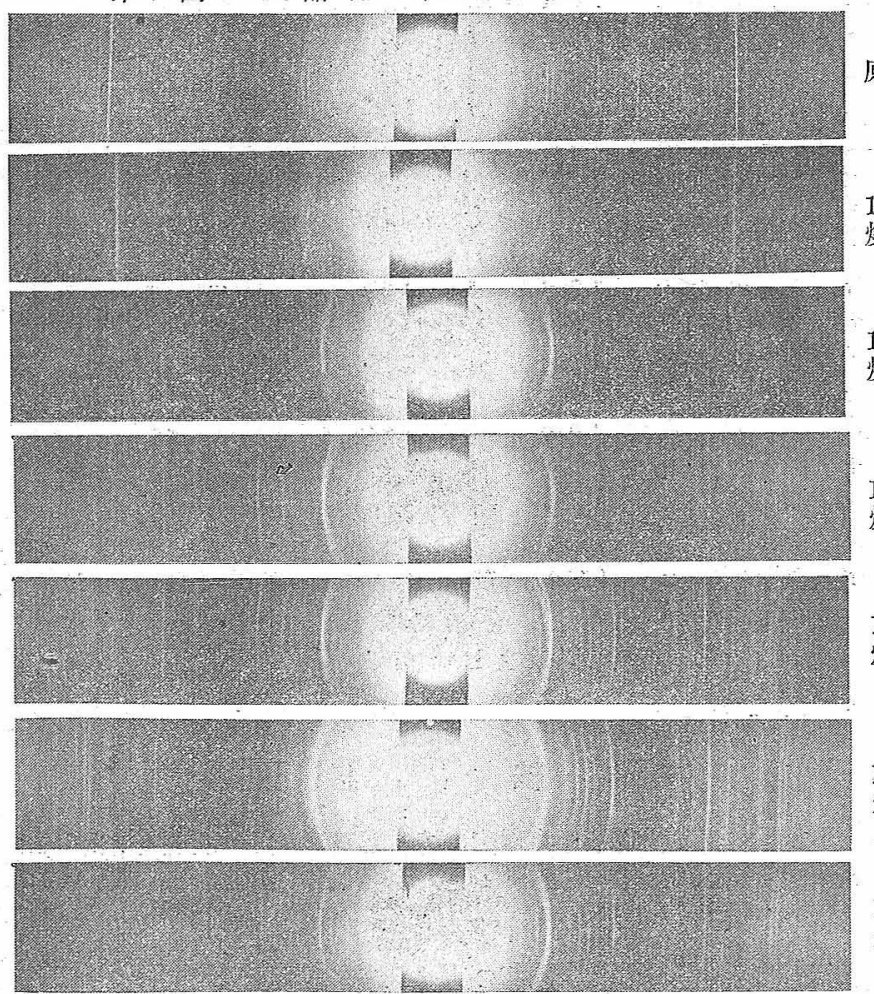

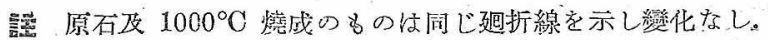

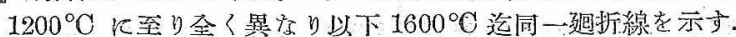
郎亏 $1200^{\circ} \mathrm{C}$ 飞於て分解し $3 \mathrm{Al}_{2} \mathrm{O}_{3} \cdot 2 \mathrm{SiO}_{2}+\mathrm{SiO}_{2}$ となる。此 の際 $\mathrm{SiO}_{2}$ は Glass 質となり，X線名折線を與へ從って Mullite の用折線のみ顯れる。原子面閒隔巫で比较强度は Bowen \& Greig の Mullite と一致す.
第 1 表 シリマナイト度ムライトの㢠折線比較表

\begin{tabular}{|c|c|c|c|c|c|}
\hline & 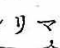 & ナイト & & & \\
\hline Nor & & Navias 氏 & Nor & & Navis 氏 \\
\hline$\alpha(\AA)$ & I & $d(\AA)$ & $d(\AA)$ & I & $d(\AA)$ \\
\hline 3.45 . & $\begin{array}{l}1 \\
\mathrm{~s}\end{array}$ & 3.45 & 3.44 & $\mathrm{~s}$ & 345 \\
\hline 2.91 & $\mathrm{f}$ & 2.92 & 2.91 & f & 2.92 \\
\hline 2.69 & $\mathrm{~m}$ & 2.72 & 2.72 & $\mathrm{~m}$ & 2.71 \\
\hline 2.55 & $\mathrm{~s}$ & 2.57 & 2.55 & $\mathrm{~s}$ & 2.57 \\
\hline 243 & $\mathrm{f}$ & 2.45 & 2.38 & $f$ & 2.45 \\
\hline 2.30 & ff & 2.30 & & & 2.31 \\
\hline 2.21 & $\mathrm{~s}$ & 2.23 & 2.22 & $\mathrm{~s}$ & 2.22 \\
\hline 2.12 & $\mathrm{~m}$ & 2.13 & 2.10 & $m$ & 2.14 \\
\hline & & 1.99 & & & \\
\hline & & 1.88 & & & 1.91 \\
\hline & & 1.84 & & & 1.85 \\
\hline & & 1.80 & & & \\
\hline 1.70 & $\mathrm{~m}$ & 1.71 & 1.72 & $\mathrm{~m}$ & 1.71 \\
\hline & & 1.69 & & & \\
\hline 1.60 & $\mathrm{~m}$ & 1.61 & 1.61 & $\mathrm{~s}$ & 1.60 \\
\hline 1.57 & $f$ & 1.57 & & & \\
\hline 1.53 & $\mathrm{~s}$ & $1.53=$ & 1.52 & $s$ & 1.53 \\
\hline 1.45 & $\mathrm{~m}^{\prime}$ & 1.45 & 1.45 & $\mathrm{~m}$ & 1.45 \\
\hline & & 1.42 & & & \\
\hline & & 1.40 & & & 1.41 \\
\hline $1: 33$ & $\mathrm{~s}$ & 1.33 & 1.34 & $\mathrm{~m}$ & 1.33 \\
\hline 1.27 & $\mathrm{~m}$ & 1.275 & 1.27 & $\mathrm{~m}$ & 1.270 \\
\hline 1.25 & f & 1.255 & 1.24 & f & 1.240 \\
\hline & & 1.235 & & & \\
\hline
\end{tabular}

Greig 氏 (J.Amer.Ceram.Soc., 1925, 8, 465) の研究に依ると 藍晶石は $1000^{\circ} \mathrm{C}$ 迄は變化なく，1100C に於て長時間保てばムライ トとシリカに僅かながら分解する，それ以上の溫度では分解は早く なり容積の霄大と組織の破壤を來す。紅柱石は $1325^{\circ} \mathrm{C}$ 迄は變化な く $1400^{\circ} \mathrm{C}$ に於てはムライトとシリカに分解しそれより溫度が高く なる程分解は早くなり完全になるとし，“更に球線石は $1345^{\circ} \mathrm{C}$ では 分解せず $1550^{\circ} \mathrm{C}$ に於て少し分解し $1750^{\circ}$ の樣な高溫に 原 石 至り分解は完全になりムライトとシリカ确子になるとし， 而して珠線不は僅かな且つ一樣な熱膨脹をするが藍晶石は 早く大なる熱膨脹をすると述べて居る.

A. B. Peck 上 (J. Amer. Ceram. Soc., 1925, 8, 407) bै 略 Greig 氏と同榜なことを述べ，加熱に低る比重の變化 は次の如くであると報䈇した。

$1200^{\circ} \mathrm{C}$
焼 成

$1300^{\circ} \mathrm{C}$

燒 成

$1400^{\circ} \mathrm{C}$

烍 成

$1500^{\circ} \mathrm{C}$ 烧 成

$1600^{\circ} \mathrm{C}$ 燒 成

\begin{tabular}{|c|c|c|}
\hline & 比 & 重 \\
\hline & 不 & S.K 15 燒成後 \\
\hline $\begin{array}{l}3.29 \\
3.59\end{array}$ & & $\begin{array}{l}3.20 \\
3.09\end{array}$ \\
\hline 3.15 & & 2.92 \\
\hline
\end{tabular}

これに依ると紅桂石が一番變化が少く珠線石は僅か膨脹 乙藍晶石が最も大きく膨脹する事となるが，若しも最終生 成分が同二のものなら比重も同じになるできで岕ららから 上記の如く SK 15 番程度の燒成では未代分解が完全でな いのであ 5 5. 最近に至り F. H. Riddle \& A. B. Peck 兩氏 (J.Amer.Ceram. Soc., 1935, 18, 193) は理線石屬の 銈物はどれでる加熱に依る最終生成物は多分同一でムライ トとシリカの混合物になるものと考へ，而して其の比重は Shepherd, Rankin，\&Wright 氏等がシリマナイト（其 の當時は未芯ムライトの研究充分に進委ず）に與へた比重 3,031 (此の數字は Bowen \& Greig に依つても確められて 居る)に近づくと述べた。

\section{（3）籃晶石の加爇變化}

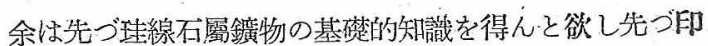
度產の藍晶石の加熱變化に就き $\mathrm{X}$ 線的に硎究を行つた。 
第 2 表 印度產藍晶石の分析結果(\%)

$\begin{array}{lllllll}\text { Ig.loss } & \mathrm{SiO}_{2} & \mathrm{Al}_{2} \mathrm{O}_{3} & \mathrm{Fe}_{2} \mathrm{O}_{3} & \mathrm{TiO}_{2} & \mathrm{CaO} & \mathrm{MgO}\end{array}$ $0.93 \quad 37.06 \quad 57.77 \quad$ tr. tr. $2.07 \quad$ tr.

$\mathrm{Al}_{2} \mathrm{O}_{3} \cdot \mathrm{SiO}_{2}$ の理論值は $\mathrm{SiO}_{2} 37.1 \%, \mathrm{Al}_{2} \mathrm{O}_{3} 62.9 \%$ でるから試 料は咯 $\mathrm{Al}_{2} \mathrm{O}_{3} \cdot \mathrm{SiO}_{2}$ より成つて居ると考へられる. 原石の外觀は黄 灰色，大きく柱狀及び針狀の結晶が發達して居る. 歞微鏡下では結
晶は科消光をなし，重屈折 0.01 程度，光學的に正，多色性弱く， 從來報ぜられた三斜晶系に屬すと言はれて居る所と一致する，本試 料は藍晶石なる事明かである.

著者は原石を粗碎しこれを電氣爐中に於て各溫度に 3 時間宛加熱 燒成し空中に於て冷却した後粉碎し夫等の比重測定並にX 線分析を 行つた. 第 3 表は其の結果である.

第 3 表蔡晶石及其の燒成物 $\mathrm{X}$ 線分析結果

\begin{tabular}{|c|c|c|c|c|c|c|c|c|c|c|c|c|c|c|c|c|}
\hline \multirow{2}{*}{$\begin{array}{l}\text { 燒成溫度 } \\
\text { 比重 } \\
\text { 線番號 }\end{array}$} & \multirow{2}{*}{ } & \multirow{2}{*}{$\underbrace{3.61}_{d(\AA)}$} & \multirow[b]{2}{*}{$I$} & \multicolumn{2}{|c|}{$\begin{array}{c}1000^{\circ} \mathrm{C} \\
3.59\end{array}$} & \multicolumn{3}{|c|}{$\begin{array}{c}1200^{\circ} \mathrm{C} \\
3.08\end{array}$} & \multicolumn{2}{|c|}{$\begin{array}{c}1300^{\circ} \mathrm{C} \\
3.04\end{array}$} & \multicolumn{2}{|c|}{$\begin{array}{c}1400^{\circ} \mathrm{C} \\
3.04\end{array}$} & \multicolumn{2}{|c|}{$\begin{array}{c}1500^{\circ} \mathrm{C} \\
3.03\end{array}$} & \multicolumn{2}{|c|}{$\begin{array}{c}1600^{\circ} \mathrm{C} \\
3.04\end{array}$} \\
\hline & & & & $d(\AA$ & $I$ & $l_{\mathrm{mm}}$ & $d(\AA)$ & $I$ & $d(\AA)$ & $I$ & $d(\AA$ & $I$ & $d(\AA)$ & $I$ & $d(\AA)$ & $I$ \\
\hline 1 & 13,726 & 4,423 & ff & 4,425 & ff & 11,193 & 5,524 & ff & 5,524 & $\mathrm{f}$ & 5,524 & $\mathrm{f}$ & 5,524 & $\mathrm{~m}$ & 5,524 & $\mathrm{~m}$ \\
\hline 2 & 14,212 & 4,2 & ff & - & - & 13,518 & 4,547 & ff & 4,547 & $\mathrm{f}$ & 4,547 & $\mathrm{f}$ & 4,547 & $\mathrm{~m}$ & $4,54: 7$ & $\mathrm{~m}$ \\
\hline 3 & 16,814 & 3,600 & $\mathrm{ff}$ & 3,601 & ff & - & - & - & 4,109 & $\mathrm{f}$ & 4,409 & $\mathrm{ff}$ & 4,109 & ff & 4,109 & $\mathrm{ft}$ \\
\hline 4 & 17,520 & 3,467 & ff & 3,467 & ff & 16,172 & 3,774 & $\mathrm{f}$ & 3,774 & $\mathrm{f}$ & 3,774 & $\mathrm{~m}$ & 3,774 & $\mathrm{~m}$ & 3,774 & $\mathrm{~m}$ \\
\hline 5 & 18,006 & 3,365 & $\mathrm{~s}$ & 365 & $\mathrm{~s}$ & 17,793 & 3,409 & $\mathrm{sS}$ & , 409 & Ss & & Ss & 3,409 & ss & 3,409 & ss \\
\hline 6 & 19,015 & 184 & $\mathrm{~s}$ & 3,184 & $\mathrm{~s}$ & 19,002 & 3,210 & & 210 & $\mathrm{ff}$ & 3,210 & if & 3,210 & ff & 3,210 & ff \\
\hline 7 & 20,748 & 2,921 & fí & 2,921 & $\mathrm{f}$ & 21,127 & 3,053 & f. & 3,053 & ff & 3,053 & $\mathrm{~m}$ & 3,053 & $\mathrm{~m}$ & 3,053 & $\mathrm{~m}$ \\
\hline 8 & 22,722 & 670 & $\mathrm{~m}$ & 670 & $\mathrm{f}$ & 21,6 & 2,881 & ff & 2,881 & $\mathrm{f}$ & 2,881 & & 2,881 & $\mathrm{f}$ & 2,881 & $\mathrm{f}$ \\
\hline 9 & 23,850 & 547 & ff & 2,547 & ff & 22,5 & 2,693 & $\mathrm{~s}$ & 2,693 & $\mathrm{~s}$ & 2,693 & & 2,693 & $\mathrm{~s}$ & 2,693 & $\mathrm{~s}$ \\
\hline 10 & 24,412 & 2,491 & $\mathrm{~m}$ & 2,491 & $\mathrm{~m}$ & 23,988 & 2,542 & $\mathrm{~s}$ & 2,542 & $\mathrm{~s}$ & 2,543 & $\mathrm{~s}$ & 2,542 & $\mathrm{~s}$ & 2,542 & $\mathrm{~s}$ \\
\hline 11 & 26,217 & 2,325 & $\mathrm{~m}$ & 2,325 & $\mathrm{~m}$ & 25,11 & 2,432 & $\mathrm{~m}$ & 2,424 & $\mathrm{~m}$ & 2,424 & $\mathrm{~m}$ & 2,424 & $\mathrm{~m}$ & 2,424 & $\mathrm{~m}$ \\
\hline 12 & 28,001 & 2,183 & f & - & - & 26,002 & 2,286 & f & 2,286 & $\mathrm{f}$ & 2,286 & $\mathrm{f}$ & 2,286 & $\mathrm{f}$ & 2,286 & $\mathrm{f}$ \\
\hline 13 & 28,672 & 2,135 & f & 2,135 & $\mathrm{f}$ & 26,781 & 2,201 & $\mathrm{~s}$ & 2,201 & $\mathrm{~s}$ & 2,201 & s & 2,201 & $\mathrm{~s}$. & 201 & $\mathrm{s}$ \\
\hline 14 & 29,157 & 2,102 & $\mathrm{f}$ & - & - & 27, & 2,115 & $\mathrm{~m}$ & & $\mathrm{~m}$ & 2,115 & $\mathrm{~m}$ & 2,115 & $\mathrm{~m}$ & 2,115 & $\mathrm{~m}$ \\
\hline 15 & 29,855 & 2,056 & $\mathrm{f}$ & $\rightarrow$ & - & 28 , & 2,005 & $\dot{1}$ & 2,005 & $f$ & 2,005 & $\mathrm{f}$ & 2,005 & $\mathrm{f}$ & 2,005 & $\mathrm{f}$ \\
\hline 16 & 31,405 & 961 & ff & - & - & 31, & 1,939 & $\mathrm{f}$ & - & - & - & - & -. & - & - & - \\
\hline 17 & 32,038 & 1,925 & $\mathrm{~s}$ & 1,925 & $\mathrm{~s}$ & 32,0 & 1,913 & $\mathrm{~m}$ & - & - & - & $\ldots$ & - & - & - & - \\
\hline 18 & 33,576 & 1,844 & $\mathrm{~s}$ & 1,844 & $\mathrm{~s}$ & 32,849 & 1,890 & $\mathrm{f}$ & 1,890 & $\mathbf{f}$ & 1,890 & $\mathrm{f}$ & 1,890 & $\mathrm{f}$ & 1,890 & $\mathrm{f}$ \\
\hline 19 & 33,252 & 1,757 & $\mathrm{f}$ & - & - & 33,785 & 1,835 & $\mathrm{f}$ & 1,835 & $\mathrm{f}$ & 1,835 & $\mathrm{f}$ & 1,835 & $\mathrm{f}$ & 1,835 & $\mathrm{f}$ \\
\hline 20 & 36,192 & 1,723 & $\mathrm{f}$ & 1,723 & $f$ & 35,627 & 1,752 & $\mathrm{f}$. & 1,752 & $\mathrm{f}$ & 1,752 & ff & 1,752 & $\mathrm{ff}$ & 1,752 & ff \\
\hline 21 & 38,274 & 1,732 & ff & 1,732 & $f$ & 36,630 & 1,702 & $\mathrm{~m}$ & 1,702 & ff & 1,702 & $\mathbf{f}$ & 1,702 & $\mathrm{~m}$ & 1,702 & $\mathrm{~m}$ \\
\hline 22 & 39,722 & 1,588 . & $\mathrm{ff}$ & 1,588 & $\mathrm{f}$ & 37,212 & 1,694 & $\mathrm{n}$ & 1,694 & $\mathrm{~m}$ & 1,694 & $\mathrm{~m}$ & 1,694 & $\mathrm{~m}$ & 1,694 & $\mathrm{~m}$ \\
\hline 23 & 40,648 & 1,557 & $\mathrm{f}$ & 1,557 & $\mathrm{~m}$ & 39,596 & 1,601 & $\mathrm{~m}$ & 1,601 & $\mathrm{~m}$ & 601 & $\mathrm{~m}$ & 1,601 & $\mathrm{~m}$ & 1,601 & $\mathrm{~m}$ \\
\hline 24 & 43,086 & 1,489 & fi & 1,487 & $\mathrm{f}$ & - & - & - & 1,574 & $\mathrm{~m}$ & 1,574 & $f$ & 1,574 & ff & 1,574 & ff \\
\hline 25 & 43,494 & 1,410 & ff & 1,410 & $\mathrm{f}$ & 41,836 & 1,515 & $\mathrm{~s}$ & 1,515 & $\mathrm{~s}$ & 1,515 & $\mathrm{~s}$ & 1,515 & $\mathrm{~s}$ & 1,515 & \\
\hline 26 & 44,473 & 1,443 & $\mathrm{f}$ & 1,443 & $\mathrm{~m}$ & 43,525 & 1,460 & ff & 1,460 & ff & 1,460 & if & 1,460 & ff & 1,460 & ff \\
\hline 27 & 45,467 & 1,413 & ff & - & - & 44,735 & 1,435 & $\mathrm{~m}$ & 1,435 & $\mathrm{~m}$ & 1,435 & $\mathrm{~m}$ & 1,435 & $\mathrm{~m}$ & 1,435 & $\mathrm{~m}$ \\
\hline 28 & 47,845 & 1,360 & ff & 1,360 & $\mathrm{~m}$ & 46,178 & 1,397 & $\mathrm{ff}$ & 1,397 & ff & 1,397 & ff & 1,397 & $\mathrm{ff}$ & 1,397 & ff \\
\hline 29 & 48,574 & 1,345 & ss & 1,345 & ss & 46,615 & 1,386 & $\mathrm{fi}$ & 1,386 & ff & 1,386 & ff & 1,386 & ff & 1,386 & ff \\
\hline 30 & 50,500 & 1,305 & $\mathrm{~m}$ & 1,304 & $\mathrm{~m}$ & 47,375 & 1,369 & $\mathrm{~m}$ & - & - & - & - & - & - & - & - \\
\hline 31 & 53,001 & $1,25^{a}$ & $£$ & 1,259 & $\mathrm{ff}$ & $49,04.5$ & 1,336 & $\mathrm{f}$ & 1,336 & ff & 336 & $\mathrm{f}$ & 336 & $\mathbf{f}$ & ,336 & \\
\hline 32 & 56,655 & 1,190 & ff & 1,191 & If & 49,436 & 1,324 & f & 24 & f & 1,324 & $\mathrm{f}$ & 1,324 & $\mathrm{f}$ & 1,324 & $\mathrm{f}$ \\
\hline 33 & 59,712 & 1,158 & i & $1,1.58$ & if & - & - & - & 1,280 & $\mathrm{f}$ & 1,280 & $\mathrm{~m}$ & 1,280 & $\mathrm{~m}$ & 1,280 & $\mathrm{~m}$ \\
\hline 34 & 62,868 & 1,122 & $\mathrm{f}$ & 1,123 & $\mathrm{ff}$ & 52,401 & 1,28 & f & 1,265 & $f$ & 1,285 & $\mathrm{~m}$ & 1,265 & $\mathrm{~m}$ & 1,265 & $\mathrm{~m}$ \\
\hline 35 & - & - & - & - & - & 53,302 & 1,252 & $\mathrm{~m}$ & 1,252 & $\mathrm{~m}$ & 1,252 & $\mathrm{~m}$ & 1,252 & $\mathrm{~m}$ & 1,252 & $\mathrm{~m}$ \\
\hline 36 & - & - & - & - & - & 55,109 & 1,223 & ff & 1,223 & ff & 1,223 & ff & 1,223 & ff & 1,223 & ff \\
\hline 37 & - & - & - & - & - & 56,726 & 1,199 & $\dot{t}$ & 1,199 & $\mathrm{f}$ & 1,199 & $\mathrm{f}$ & 1,199 & $\mathrm{f}$ & 1,199 & \\
\hline 38 & - & - & - & -- & - & 57,284 & 1,191 & $\mathrm{f}$ & 1,191 & $\mathrm{f}$ & 1,191 & $\mathrm{f}$ & 1,191 & $\mathrm{f}$ & 1,191 & \\
\hline 39 & - & - & - & - & - & 60,423 & 1,150 & ff & 1,150 & ff & 1,150 & fí & 1,150 & ff & 1,150 & \\
\hline
\end{tabular}

上記分析結果より次の事が明かである.

藍晶石は $1100^{\circ} \mathrm{C}$ 汽は加熱變化は起らないが $1200^{\circ} \mathrm{C}$ に筀成され たものは完全に變化し $1300 \sim 1600^{\circ} \mathrm{C}$ に燒成されたものと全く同じ である，而して $1200^{\circ} \mathrm{C}$ 以上のもの〉迥折線は線番號 $5,9,10,11$ ， $13 ， 14,21 ， 23 ， 25 ， 27,33 ， 35$ 等に於て原子面間隔並に比較强度 共に Norton 氏又は Navias 氏等のムライトのの迴折線と殆ど一致 した，而して著者の趣折線は兩氏のるのより遥加に數が多いので或 は遊離の $\mathrm{SiO}_{2}$ がクリストバライト或は鱗石英にでもなつて居りは しないかて考へ檢討して見たが夫等の特性目折線は全く含ま㨾で あり，從つて遊離の珄酸硝子になつて居ると考へられた．斯くして 藍晶不は $1200^{\circ} \mathrm{C}$ に於て既に完全にムライト及び珠酸硝子になる事 は明かである. 此の事は比重より見ても明かである. 佮又此の比重 の變化の大なる點よりして珪不よりも遥かに大なる熱膨脤をなす事
も明かである. 著者の結果は Bowen \& Greig 氏等の研究結果に近 い樣である。

總 狧

本報に於ては監晶石を各溫度に憢成し其の比重の變化を求め更に 結晶變化を $\mathrm{X}$ 線的に研究した結果, 藍晶石は $1100^{\circ} \mathrm{C}$ と $1200^{\circ} \mathrm{C} の$ 間に於て分解をし， $1200^{\circ} \mathrm{C}$ に於ては完全に分解しムライト及び珪酸 硝子になる事を示した。原石の比重 3.61 , 分解生成物 の比重は 3.04 附近であつた。

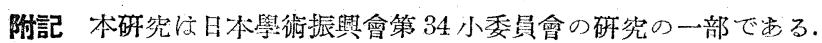
(昭和 14. 8. 28. 早稳田大學理工學部應用化學科研究室に於て) (昭 14.8.29 受附) 